\title{
Upgrading Methane Using Ultra-Fast Thermal Swing Adsorption
}

\author{
Quarterly Report \\ April 1, 2005 - June 31, 2005
}

by

Anna Lee Tonkovich

July 2005

DE-FC26-03NT41905

\author{
Velocys \\ 7950 Corporate Boulevard \\ Plain City, Ohio 43064 \\ Subcontractor \\ Joseph D'Amico \\ 6422 Oak Park Court \\ Linthicum, MD 21090
}


This report was prepared as an account of work sponsored by an agency of the United States Government. Neither the United States Government nor any agency thereof, nor any of their employees, makes any warranty, express or implied, or assumes any legal liability or responsibility for the accuracy, completeness, or usefulness of any information, apparatus, product, or process disclosed, or represents that its use would not infringe privately owned rights. Reference herein to any specific commercial product, process, or service by trade name, trademark, manufacturer, or otherwise does not necessarily constitute or imply its endorsement, recommendation, or favoring by the United States Government or any agency thereof. The views and opinions of authors expressed herein do not necessarily state or reflect those of the United States Government or any agency thereof. 


\section{Abstract}

The purpose of this project is to design and demonstrate an approach to upgrade low-BTU methane streams from coal mines to pipeline-quality natural gas. The objective of Phase I of the project was to assess the technical feasibility and cost of upgrading low-BTU methane streams using ultra-fast thermal swing adsorption (TSA) using Velocys' modular microchannel process technology. The objective of Phase II is to demonstrate the process at the bench-scale.

Natural gas upgrading systems have six main unit operations: feed compressor, dehydration unit, nitrogen rejection unit, deoxygenator, carbon dioxide scrubber, and a sales compressor. The NRU is the focus of the development program, and a bench-scale demonstration has been initiated. The Velocys NRU system targets producing methane with greater than $96 \%$ purity and at least $90 \%$ recovery for final commercial operation. A preliminary cost analysis of the methane upgrading system, including the Velocys NRU, suggests that costs below $\$ 2.00$ per million (MM) BTU methane may be achieved. The cost for a conventional methane upgrading system is well above \$2.30 per MM BTU, as benchmarked in an Environmental Protection Agency study.

The project is on schedule and on budget. Task 4, a bench-scale demonstration of the ultra-fast TSA system is complete. Rapid thermal swing of an adsorbent bed using microchannels has been successfully demonstrated and the separation of a $70 \%$ methane and $30 \%$ nitrogen was purified to $92 \%$ methane. The bench-scale demonstration unit was small relative to the system dead volume for the initial phase of experiments and a purge step was added to sweep the dead volume prior to desorbing the bed and measuring purity.

A technical and economic feasibility assessment was completed in Task 3. The proposed Velocys technology appears feasible for the methane upgrading market. Evaluated categories include adsorbent selection, rapid-cycle valve selection, microchannel manufacturability assessment, and system design and cost.

The selected adsorbent, granular microporous carbon from either Barnaby-Sutcliffe or Calgon, experimentally demonstrated sufficient methane capacity under differential temperature at 100 pounds per square inch gauge. Several valve options were identified, including candidates that can operate millions of cycles between refurbishment. The microchannel adsorber and desorber designs were made using internal Velocys manufacturability standards, and the associated costs are acceptable as included with the complete nitrogen rejection unit (NRU) cost projection. A system design and cost estimate was completed for the NRU section of the methane upgrading system. As integrated into the complete system, the cost is in line with the market requirement. 


\section{Table of Contents}

Executive Summary .................................................................................... 1

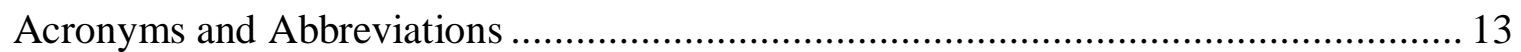




\section{Executive Summary}

Essentially no work was performed this quarter with the exception of the planning effort for the next phase of development.

Project 41905, Upgrading Methane Using UltraFast Thermal Swing Adsorption, Velocys Inc. 


\section{Acronyms and Abbreviations}

$\begin{array}{ll}\text { Btu } & \text { British thermal unit } \\ \text { GHG } & \text { greenhouse gas } \\ \text { gm } & \text { gram } \\ \text { GWP } & \text { global warming potential } \\ \text { HPBV } & \text { high-performance butterfly valve } \\ \text { kg } & \text { kilogram } \\ \text { mg } & \text { milligram } \\ \text { MMSCFD } & \text { million standard cubic feet per day } \\ \text { MW } & \text { megawatts } \\ \text { NRU } & \text { nitrogen rejection unit } \\ \text { psig } & \text { pound per square inch gauge } \\ \text { SLPM } & \text { standard liters per minute } \\ \text { TSA } & \text { thermal swing adsorption }\end{array}$

